\title{
KONSEP TUHAN PADA ANAK USIA AKHIR OPERASIONAL KONKRET
}

\author{
Duma Rachmat Artanto \\ Universitas Gadjah Mada
}

\begin{abstract}
The concept and perception of religion is shaped not only by a process of ideas transformation. There are many factors that involved in influencing it. This research aimed to identify the concept of God, ifs characteristics, its factors and the psychological dynamic of children in late operational concrete of Plagef's cognitive devoiopment to formulate the concept of God. Date were obtained through in-depth interview with 2 (two) children of 10-11 years old, muslims, having their parents permissions, able to communicate and living in Yogyakarta.

Data were also obtained from both parents (mother and father) and religion teacher. The resoarch was ablo to identify somjo findings: God is the creator of wholo wortd, God could make anything He want fo, mankind could contact Him through prayer. The Charactreristics of God concept in this period are (1) doctrin, (2) lack of ideas originality, (3) ldeas of God dovoiop from personai God to impersonal God, (4) God is kind, (5) relation to God via prayer, (6) two kind of God-mankind relationshipare transactional reiationship and ioarning by-consequenco reiationship, (7) the doveiopment of guilty feeling as a sign of the well developed conscience.
\end{abstract}

Key words: Concept of God, ideas, ideas transformation.

\section{Pengantar}

roses terbentuknya konsep Tuhan pada anak umumnya dipahami sebagai proses transformasi (pengalihan) gagasan dari orang dewasa (orangtua dan guru) kepada anak-anak. Tuhan dipahami anakanak karena lingkungan memberi pemahaman kepadanya. Realitas Tuhan memang tidak tampak dan belum pernah dilihat anak. Walaupun demikian gagasan mengenai Tuhan dan keberadaan-Nya mau tidak mau akan diterima anak karena seluruh lingkungan di mana anak tinggai sepertinya tidak ada yang tidak mengenal Tuhan (Stoppard, 1997). Semua orang mengenal Tuhan, menyebut dan merapalkan namaNya dalam doa-doa, pembicaraan, dan aktivitas sehari-hari. Hampir seluruh aktivitas selalu dihubungkan dengan Tuhan: berdoa ketika sebelum-sesudah makan, ketika akan berangkat maupun pulang sekolah, dan semua doa dikatakan pada anak ditujukan padaTuhan.
Ketika ada yang meninggal akan dikatakan pada anak kalau yang meninggal itus sedang kembali kepada Tuhan. Ketika ada hujan, badai, angin, ayam, atau adik baru dikatakan kepada anak bahwa semua itu yang menciptakan adalah Tuhan. Namun Tuhan juga didengar anak dalam ancamanancaman orang dewasa ketika anak mulai tidak patuh, nakal, dan susah diatur. Tuhan yang akan menghukum siapa saja yang tidak patuh pada perintah-perintah-Nya dan melanggar semua larangan-larangan-Nya (Hurlock, 2000).

Adanya anggapan bahwa proses terbentuknya konsep Tuhan pada anak hanya terjadi karena proses tranformasi gagasan semata seringkali membuat orangtua dan guru memahami bahwa pendidikan agama tu dliangsungkan dengan jalan mentransfor sebanyak mungkin pengetahuan agama dan Tuhan pada anak. Pengajaran agama akhirnya cenderung ditekankan pada aspek kognitif. Dugaan peneliti ini didasarkan pada fakta pengajaran 
agama yang dilakukan di sekolah-sekolah tidak jauh berbeda dengan dengan pengajaran IPA, Bahasa, dan IPS (Hidajati, 2002). Pendidikan agama cenderung diartikan sebagai penyampaian dogma atau pengetahuan mengenai agama tertentu (Darmaningtyas, 1999) yang harus diterima dan lidak boleh dipertanyakan.

Pengaruhnya mungkin tidak terasa, namun sosok Tuhan yang diberikan dengan lebih menitikberatkan pada aspek kognitif, jelas akan kesulitan untuk dihadirkan sebagai teman dialog. Anak dapat menjelaskan keberadaan Tuhan dengan panjang lebar namun jelas tidak secara langsung membuat anak merasakan kehadiran Tuhan. Proses inilah yang menyebabkan pendidikan agama gagal menumbuhkan kearifan, kesadaran, dan pengalaman ketuhanan (Mulkhan, 2002).

Kegagalan pendidikan agama mungkin tidak akan terjadi kalau pemahaman mengenai terbentuknya konsep Tuhan pada anak bukan hanya dipahami sebagai proses tranformasi gagasan semata. Goldman (1964) menyatakan bahwa proses terbentuknya pemikiran religius pada anak bukan hal yang sederhana, namun suatu hal yang kompleks. Kompleksnya pemikiran religius pada anak karena dihasilkan dari proses generalisasi terhadap berbagai pengalaman, persepsi terdahulu, dan berpegang pada konsep yang telah ada untuk mengartikan aktivitas dan sifat-sifat dasar Tuhan. Misalnya, ada perkataan "Tuhan ilu satu, Mahadekat dan Dia ifu ada of mana-mana"', maka ketika anak berusaha memahaml ini anak akan menggunakan konsep dan pengetahuan yang diketahuinya. Anak membutuhkan konsep: ruang, waktu, jarak dan bilangan, di mana semua konsep inl didapatkan dari banyak hal termasuk kedekatan orangtua terhadap anak.

Pendapat Goldman (1964) di atas memberikan kejelasan bahwa bukan hanya masalah bagaimana kepercayaan orang dewasa dialihkan, tetapi juga terkait dengan bagaimana orangtua memunculkan gagasan ketuhanan di dalam dirinya, termasuk di dalamnya bagaimana orangtua memandang dirinya dan bagaimana orangtua memperlakukan si anak.

Alasan lain dilakukannya penelitian ini adalah karena peneliti merasa wilayah gagasan anak mengenai Tuhan sudah men jadi berat sebelah, cenderung mengarah pada Tuhan sebagai sosok yang menakutkan dan sosok penghukum kesalahan manusia. Sosok Tuhan jauh dari sosok yang menyenangkan dan menentramkan, apalagi sebagai sosok teman yang asyik untuk diajak berdialog dan berbagi rasa. Tuhan ditampilkan sebagai sosok yang menyenangi seseorang karena melakukan apa saja yang diperintahkan padanya dan menghukum orang yang tidak patuh pada perintah Tuhan. Sosok Tuhan lebih sering terpadankan dengan kata "neraka", "hukuman dan siksaan", atau "api yang menyala-nyala". Sosok Tuhan yang hitam putih cermin wilayah gagasan dan sikap keberagamaan orang dewasa di sekitar anak.

Dugaan peneliti didasarkan pada fakta bahwa pengenalan Tuhan yang menjadi tujuan pendidikan agama pada anak yang dilakukan di rumah, sekolah ataupun di tempat-tempat peribadatan sepertinya lebih menitikberatkan pada aspek hukum (syariat dalam agama Islam). Aspek ini lebih menekankan aturan-aturan dan laranganlarangan, yang merupakan anjuran hldup orang yang beragama dan mempunyai Tuhan (Hidajati, 2002). Penitiberatan pada aspek hukum inl sebenarnya adalah kehendak baik dari orangtua untuk mengajarkan kebaikan perilaku tertentu. Anak diajarkan bahwa hal tertentu balk untuk dikerjakan manusia sementara sesuatu yang lain adalah bunk dan harus dihindari. Pertimbangan yang diambil karena anak dianggap belum mempunyai kemampuan logis yang memadai untuk menentukan kebenaran perilakunya (Daradjat, 1993).

Seiring dengan pengajaran mengenai aturan dan tarangan, anak tidak pernah atau jarang diajak untuk mengenal keindahan ibadah, mengapa Tuhan memerintahkan suatu perbuatan dan meminta manusia menjauhi perbuatan yang lain atau hikmah d balik segala sesuatunya. Padahal Inilah sesungguhnya yang lebih disukal oleh anak. 
karena akan mengembangkan wawasan anak dalam beragama. Anak akan lebih mengerti, bahwa ada yang lebih penting untuk diketahul di balik pelajaran agama, yaitu penghayatan dan pengamalan (Hidajati, 2002).

Penelitian ini dilakukan terhadap anak usia akhir operasional konkret menurut tahapan kognitif Jean Piaget (10-11 tahun).Anak-anak yang berada pada tahapan operasional konkret tahapan kognitif Jean Plaget sudah mampu mengembangkan pemiklran logis yang akan membantu anak untuk memecahkan permasalahanpermasalahan yang dihadapinya. Anak memang belum mampu sepenuhnya menerapkan kemampuan itu pada hal-hal yang bersifat abstrak (Suparno, 2001), namun anak telah mengembangkan gaya berpikir yang sudah tidak egosentris sehingga sudah dapat membandingkan apa yang dipikirkannya dengan apa yang dipikirkan deh orang lain.

Tahap operasional konkret ditandai dengan adanya sistem operasi berdasarkan apa-apa yang kelihatan nyata atau konkret. Anak masih menerapkan logika berpikir pada barang-barang yang konkret, belum bersifat abstrak apalagl hlpotetis. Anak maslh mempunyai kesulitan untuk memecahkan persoalan yang mempunyai banyak variabel. Inteligensi pada tahap ini sudah sangat maju, meskipun cara berpikir seorang anak tetap masih terbatas karena masih berdasarkan sesuatu yang konkret (Suparno, 2001) Anak apabila dihadapkan dengan suatu masalah secara verbal, yaitu tanpa adanya bahan yang konkret, anak belum mampu untuk menyelesaikan masaiah ini dengan baik (Mönks dkk., 1999).

Pada masa usia íni secara sosial, anak telah memasuki sekolah, lingkungan di mana anak akan bertemu dengan guru yang akan mengajarkan banyak hal termasuk di antara Tuhan beserta ciptaan-Nya, bertemu dengan teman-temannya yang mempunyai latar belakang berbeda. Mungkin bagi salah seorang anak Tuhan menjadi hal yang penting, sementara bagi anak yang lain adalah hal yang tidak begitu diperhatikan. Teman sebaya seperti menjadi tempat di mana ketidakseimbangan kognitif sering terjadi, tempat di mana anak harus menimbang-nimbang kebenaran gagasan yang dimilikinya dengan gagasan anak yang lain (Supamo, 2001).

Konsep anak mengenai Tuhan sendiri menurut Hurlock (2000) dihasilkan darf pengolahan dan kombinasi (penggabungan atau perpaduan) kesan yang terpisah-pisah mengenai hal-hal yang berkenaan dengan Tuhan. Kesan-kesan anak diperoleh melalui indera ketika bersentuhan dengan realitas keagamaan. Apa yang dilihat, didengar, dan dirasakannya mengenai Tuhan melalui rumah, dari sekolah, dari tempat-tempat ibadah, dan dari lingkungan sosial di mana anak bertempat tinggal (Rizzuto dalam Coles, 1990).

Konsep Tuhan sangat tergantung pada pengalaman-pengalaman yang pernah dialami, yang kemudian diucapkan dengan menggunakan kata dan tidak akan lepas dari proses Interpretasi terhadap kata-kata yang digunakan tadi. Ini merupakan hal yang tidak dapat terelakkansebagai daerah yang dipelajari, bahwa kata tersebut digunakan tanpa mengetahul arti yang sebenarnya dari konsep (Goldman, 1964). Churchill (Goldman, 1964) juga menegaskan ada bahaya pada saat anak mengemukakan pemikirannya mengenai hal-hal yang berkenaan dengan Tuhan adalah kemungkinan adanya manipulasi kata yang tidak dimengerti untuk mengungkapkan pemiklrannya, walau tidak memiliki konsep yang memadai.

Penelitian Ini bertujuan untuk mengetahui konsep Tuhan pada anak usia akhir operasional konkret yang beragama Islam, beserta karakteristiknya. Penelitian ini juga ingin memahaml lebih jauh mengenai faktor-faktor yang mempengaruhi terbentuknya konsep Tuhan dan dinamika psikologis pembentukan konsep Tuhan.

\section{Pertanyaan Penelitian}

1. Bagaimana konsep Tuhan pada anak usia akhir operasional konkret yang beragama Islam?

2. Faktor-faktor apa yang mempengaruhi terbentuknya konsep Tuhan pada anak usia akhir operasional konkret? 


\section{Metode Penelitian}

Dalam penelitian ini akan ada dua macam responden yang pertama adalah responden anak dan yang kedua adalah responden yang mempengaruhi dinamika psikologis terbentuknya konsep pada anak, yakni responden orangtua (ayah-ibu) dan responden guru agama di sekolah. Responden anak pada penelitian ini adalah anak yang memiliki kriteria-kriteria sebagai berikut: berumur 10-11 tahun, beragama Islam, mudah untuk diajak berkomunikasi, dan berdomisili di wilayah Yogyakarta.

Berdasarkan kriteria tersebut, peneliti mengambil dua orang responden anak. Kedua responden sama-sama menginjak kelas 6 SD dan sudah berusia 11 tahun. Keduanya juga merupokan anak pertama dari tiga bersaudara. Responden anak $\mathrm{I}_{\text {, }} \mathrm{ka}$ adalah seorang bocah perempuan bersekolah d salah satu SDIT d Kota Yogyakarta yang mewajibkan siswinya bejilbab dan sudah ada pernisahan antara laki-laki dan perempuan semenjak kelas 4. Responden anak pertama memilikj dua orang adik laki-laki (seorang sudah kelas 2 SD, sementara yang lainnya baru berumur 9 bulan). Sementara responden anak II, Yan, adalah seorang bocah laki-laki yang bersekolah di SD Negeri di Kotagede Yogyakarta dan merniliki seorang adik lakilaki ( 9 tahun) dan seorang lagi perempuan (2 tahun).

Kedua orangtua responden anak I bekerja. Ayah bekerja d sebuah PTN di Yogyakarta dan bu bekerja di sebuah bank milik pemerintah. Orangtua responden anak II keduanya juga bekerja, ayah bekerja sebagai pegawal PERUM Pegadaian dan ibu bekerja sebagai pegawai LAPAS Wirogunan bagian Pembinaan.

Kedua responden memiliki karakteristik sama yakni perasaan ingin tahu yang cukup besar. Responden anak I sering bertanya pada peneliti mengenai Psikologi, sementara responden anak II pemah beberapa kall bertanya tentang alam semesta. Minat itu semakin ditunjukkan responden anak \| ketika peneliti memperlihatkan padanya sebuah buku yang di dalamnya memuat foto beberapa galaksi. Kedua responden suka membaca, namun menurut pengamatan peneliti responden anak I tampaknya lebih mendapatkan dukungan dari orangtua untuk mengembangkan hobinya itu dibandingkan responden anak II. Responden anak II suka membaca dan its dilakukannya dengan membaca buku perpustakaan atau meminjam dari teman-temannya.

Responden kedua adalah responden orangtua dan gurs agama yang diambil datanya untuk mendapotkan gambaran yang menyeluruh bagaimana konsep Tuhan yang diyakini dan melihat bagaimana pengajaran mengenai Tuhan yang dilakukan oleh orangtua dan guru agama.

Pengumpulan data dilakukan dengan menggunakan wawancara mendalam (indepth interview). Wawancara mendalam merupakan suatu metode yang digunakan dengan melakukan suatu percakapan berdasarkan suatu maksud tertentu (Tubbs, 1996). Wawancara dapot diartikan sebagal suatu proses komunikasi diadik, relasional dengan tujuan serius dan ditetapkan terlebih dulu yang dirancang untuk mempertukarkan perilaku dan melibatkan tanya jawab (Stewart dan Cash dalam Tubbs, 1996).

Pertanyaan penelitian kemudian disusun sebagai sebuah panduan wawancara yang menggali data poda responden anak sebagal berikut: (1) konsep Juhan: wujud, sifat, perbuatan Tuhan beserta konsep-konsep lain yang berada di sekitar Tuhan (surganeraka, malaikat-iblis, doa, dosa); (2) persepsi anak mengenai orangtua (ayahibu); (3) pengalaman individual anak; (4) praktik keagamaan. Sementara pada responden orangtua digall data mengenal konsep Tuhan, pengajaran mengenai Tuhan dan hubungan Juhan dengan manusia, praktik keagamaan, pengaiaman individual dan disiplin yang diterapkan. Data yang digali dari responden guru agama adalah konsep Tuhan, pengajaran menganai Tuhan dan hubungan Tuhan dengan manusia, pengalaman individual, dan praktik keagamaan.

Data penelitian ini kemudian dianalisis secara kuaiitatif. Jorgensen (Poerwandari, 1998) mengatakan bahwa analisis adalah 
memecah, memisahkan atau membongkar misteri penelitian ke dalam potongan, bagian, elemen atau unit. Dapat dikatakan bahwa pekerjaan analisis data dalam hal ini adalah mengatur, mengurutkan, mengelompokkan dan mengkategorikan. Data yang didapatkan dari wawancara mendalam akan ditulis ke dalam bentuk transkrip verbatim dan catatan lapangan, kemudian diuntkan, dikelompokkan dan dikategorikan ke dalam tema-tema yang nantinya akan dibicarakan lebih lanjut.

\section{Hasil Penelitlan}

1. Deskripsi Umum Konsep Tuhan pada Anak

a. Tuhan"Satu".

Responden anak mempercayai bahwa Tuhan litu satu. Berikut cuplikan wawancara peneliti dengan responden.

Tuhan itu esa. Mengapa Tuhan itu esa? Karena Tuhan hanya ada satu. Kalau Tuhannya banyak gimana. nanti menciptakan ini begini begini malah jadi anu...perang berselisih. Perang antar apa? AntarTuhan. (lka)

Jadi, jadi apakah misainya dalam satu agama bisa mempunyai empat Tuhan? Bukan, kalau of dunis ini ada empat Tuhan pasti dunia itu akan pecah belah. Apa yang akan terjadi kalau ada empat Tuhan, pecah belahnya seperti apa? Perebutan kekuasaan. Perebutan kekuasaan... antara siapa dan siapa? Antara Tuhan 1 dan Tuhan 4, Tuhen 2 dan Tuhan 3. (Yan)

\section{b. Tuhan Pencipta.}

Responden anak juga menyatakan bahwa Tuhan adalah pencipta manusia dan alam semesta. Berikut ini dicuplik dari wawancara peneliti dengan responden.

Allah itu? Allah itu Tuhan Pencipta aiam. Pencipta alam? Yang menciptakan manusia dan lain-lain. Menciptakan manusia dan lain-lain. Yang lain-lain itu apa? Ya, kan ada hewan, tumbuhan, ya gitu lah. Ada yang lainnya selain hewan dan tumbuhan? Bumi. Buml. Ya, kan udah toh semesta aimm. Planet-planet lain, aiam semesta, bintang, buian. Nggak bisa dihitunglah. Semua diciptakan oleh Dia? Ya (lka)

Siapa Tuhan? Yang menciptakan alam semesta. Tuhan itu yang menciptakan alam semesta....Alam semesta itu apa aja tho? Semug isi dunia ini Selain mencipta alam semesta, mencipta apa saja? Manusia, makhluk hidup, dan sebagalnya. (Yan)

c. Tuhan itu berkuasa

Tuhan menurut kedua responden anak memiliki kekuasaan yang amat besar. Berikut cuplikan wawancara peneliti dengan responden.

Tuhan itu berkuasa atas semuanya. Semuanya itu milik Allah. Tapi kita hanya dipinjami dan bisa dipergunakan dengan baik karena besok kita olmintal pertanggungjawaban atas semuanya. (lka)

Allah Mahakuasa? Seberapa a ....Tk terhingga. Tak terhingga. Maksudnya? Ya semuanya ini milik Allah. Termasuk kamu? Yak, betul.

Tape ini gimana? itu milik Allah. Milik Allah? Kita hanya dipinjemi dan harus dipergunakan sebaik-baiknyg. (ka)

Kenapa Allah tidak menguasai, kalau tape siapa yang menguasai? Manusia. Manusia. Allah tidak menguasal tape kenapa? Allah hanya......apa namanya membuat bahan-bahannya, yang membuat menjadi tape manusia. (Yan). 
d. Tuhan itu adil

Dua responden anak menyatakan bahwa Tuhan itu memiliki keadilan terhadap manusia. Berikut ini cuplikan wawancara peneliti dengan responden.

Adil, semua orang itu diberi kecukupan. Semuanya itu diberi rezki itu yang cukup untuk memenuhi kehidupannya. Tapi tergantung orang itu bisa mempergunakan dengan baik nggak. (ka)

Allah itu adil, adil setiap manusianya. Bila manusianya berbuat jahat Allah akan membalasnya dengan perbuatan yang jahat, jika berbuat dengan baik maka akan dibalasnya dengan perbuatan baik. (Yan)

e. Tuhan itu Pengasih dan Penyayang

Responden memandang Tuhan th Pengasih dan Penyayang. Berikut ini pernyataan yang disampaikan oleh responden terhadap peneliti.

Pengasih dan Penyayang. Kalau Maha Penyayang itu gimana? Día sa.... menyayangl kita, melindungi kita dari ancaman berbahaya. Melindungi kita dari ancaman bahaya, ancaman bahaya itu apa saja tho? Yah..... misalnya. Misalnya? Misalnya ada banjir yang akan melanda kampung kita tapi tak terjadi. Tidak terjadi, ada sebabnya? Sebabnya (diam)......mungkin karena kita, mungkin karena kehendak Allah untuk melindungi kita. (Yan)

f. Tuhan tidak dapat diajak bicara.

Responden mengungkapkan bahwa Tuhan tidak dapat diajak bicara. Berikut ini akan dicuplikan wawancara peneliti dengan responden,

Pemah bicara sama Tuhan nggak? Nggak. Kenapa? Kan belum pemah ketemu. Belum pernah ketemu? Belum pernah ketemu. Belum pernah ketemu karena apa? Ya, kan belum of akhirat. Apakah memang Allah tidak kelihatan? $Y a$, begitu. Sehingga tidak bisa ditemui? Yah. Tidak bisa ditemui? Bisa, of akhirat. Bertemu itu kalau itu wajah... Berhadapan. (lka)

g. Tuhan itu baik

Dua responden anak menyampaikan bahwa Tuhan itu baik. Berikut inl kutipan wawancara peneliti dengan dua orang responden anak tersebut.

Baik. Nggak baik ya, aku nggak bakalan bisa hidup, alhamdulillah dapat int. Blsa sekolah. Semua orang ifu masih bisa hidup. Tuhan bisa jahat nggak? Bukan jahat tapi marah. Sebel. (lka)

Tidak. Kalau ...tergantung pandangan orang lain. Maksudnya gimana? Kalau pandangan orang lain orang itu bilang Tuhan ilu jahat, ya bisa dikatakan Tuhan itu jahat. Kalau pandangan orang itu jahat. (Yan)

h. Tuhan itu dapat marah tetapi juga pernaaf

Tuhan itu dapat marah tetapi sekaligus pemaaf. Berikut ini cuplikan wawancara peneliti dengan responden.

Tuhan bisa marah? Bisa. Sering marah. Pas zamannya nabi-nabl dulu. He ...he ... Kalau sekarang? Kali marah, waktu Jakarta banjir. Kenapa, kenapa Dia marah? Karena of Jakarta banyak kemaksiatan. Tadj kayak itu masalah azab tadi itu tho. Kalau ada pelanggaran terhadap hukumhukumnya Dia rnarah? Tergantung. Tergantung apa? Tergantung kalau itu bisa dimaafkan ya, dimaarkan. Kalau sudah overdosis ya, sudah. Overdosis ki piye? Keterfaluan. Oh, keterlaluan. Berarti banyak pelanggaran? Ya banyak. Terus, rnarahNya gimana? Tadi diazab. Pada siapa saja Dia marah? Pada orang-orang yang melanggar itu tadi. 
Kalau semakin banyak kesalahan apakah Dia akan semakin marah? E...ya, kan pertamanya masih dimaafin, dimaafin, dimaafin. Tapi marahnya tuh dah kalau sudah overdosis gitu tho. Kalau sudah keterlaluan Dia marah? Ya Lalu kenapa dia memaafkan? Kan Allah Maha Pemaaf. Kalau Allah... Terus? Kan mungkin itu baru pertama kali dia lakukan. Masih ada kesempatan untuk dia rubah. Begitulah kira-kira. (Ika)

L. Tuhan memerintahkansesuatu

Responden anak berpandangan bahwa Tuhan memerintahkan manusia untuk melakukan segala sesuatu yang baik. Berikut ini cuplikan pernyataan responden.

Ya, nyuruh... kalau nyuruh kita ya a, menjalankan kewajiban kita, beruat yang baik, pokoknya yang berakhlaq karimah. (lka)

Perbuatan baik itu contohnya? Perbuatan baik... sabar... Sabar? Tabah. Tabah. Terus? Rajin. Rajin. Terus? Ikhlas. (Yan)

j. Tuhan melarang sesuatu

Di samping memerintahkan sesuatu, Tuhan juga melarang manusia untuk melakukan perbuatan buruk. Berikut ini akan diungkapkan cuplikan wawancara responden dengan peneliti.

Minum khamar, makan daging babi, perbuatan-perbuatan yang buruk lah. A...dzusdhon. Dzu'udhon itu? Dzuiudhon its berprasangka buruk. (Ika)

Moncuri, meminum minuman keras. (Yan)

\section{Karakteristik KonsepTuhan padaAnak}

a. Gagasan-gagasan yang dimiliki anak mengenai Tuhan lebih merupakan doktrin yang dihasilkan dari pengajaran. Responden anak pada penelitian ini sudah banyak mengadaptasi gagasan-gagasan yang dimiliki oleh kepercayaan $d$ dalam agama. Kepercayaankepercayaan keagamaan (doktrin) yang diperoleh anak melalui pengajaran mengenai Tuhan dan hubungan Tuhan dengan manusia. Berikut ini satu gagasan yang dikemukakan oleh responden anak yang berhasil mengadaptasi gagasan yang blasanya dikemukakan di dalam agama.

Jadi, jadl apakah misalnya dalam satu agama bisa mempunyai empat Tuhan? Bukan, kalau di dunia ini ada empat Tuhan pasti dunia itu akan pecah belah. Apa yang akan terjadi kalau ada empat Tuhan, pecah belahnya seperti apa? Perebutan kekuasaan. Perebutan kekuasaan... antara siapa dan siapa? Antara Tuhan 1 dan Tuhan 4, Tuhan 2 dan Tuhan 3. (Yan)

Ini bersesuaian dengan apa yang tercantum di dalam Al Qur'an SuratAIAnbiya:: 22 "Kalau di langit dan of buml ada Tuhan selain Allah, tentu bumi dan langit itu rusak (tidak ada)"

b. Kekhasan gagasan teologis. Gagasan yang dikemukakan cenderung menyiratkan kemakuasaan Tuhan yang memang menjadi ciri dari ajaran Islam. Gagasan mengenai Tuhan sebagai pengatur, pemifik segalanya, sesuatu terjadi atas kehendak dan lzin-Nya. Gagasan-gagasan yang berasal dari pemahaman mengenal tauhid rububiyyah di dalam Islam. Berikut ini pandangan anak berdasarkan hasil wawancara dengan responden.

Yaa, aku kan hanya makhluk biasa, Terus? Yang dapat menentukan aku hidup mati kan hanya Allah, hanya Tuhan. Udah biarlah, wong aku mati sokarangnggakpapa... (Yan) 
c. Ada dua pola bagaimana Tuhan berhubungan dengan manusia, yakni hubungan transaksional dan hubungan pengajaran dengan konsekuensi.

1) Hubungan transaksional adalah hubungan Tuhan dengan manusia di mana ada perintah dan larangan yang harus dikerjakan oleh manusia. Manusia patuh dan melaksanakan perintah maka Tuhan akan memberikan pahala dan surga, sementara ketika manusia tidak patuh maka manusia akan berdosa dan Tuhan akan menghukum manusia dengan memasukkannya ke dalam neraka. Hal ini didasarkan pada pemyataan responden anak sebagai berikut:

Kalau kita tidak patuh terhadap larangan-larangan-Nya apa yang terjadi? Yah, dosanya besar. Kita sudah diazab of sini. Bisa. Selain kita nggak nyaman of sini, tapi ya kalau orang non-lslam sih nyaman-nyaman aja. Nggak nyaman of dunia, nanti di akhiraf pertanggungjawabannya besar banget. (lka)

2) Hubungan pengajaran yang didasarkan konsekuensi. Huburgan yang hampir mirip dengan hubungan transaksional bahwa Tuhan memiliki perintah yang harus dipatuhi dan larangan yang manusia dilarang untuk melanggarnya. Titik berat hubungan ini adalah pada pengajaran bahwa Tuhan dengan hukuman bukan ingin menghukum manusia namun ingin memberikan peringatan agar manusia kembali. Hal ini didasarkan pada pernyataan responden anak sebagai berikut:

Kalau tadl ada larangan, kalau kita tidak patuh, apa yang terjadi pada kita? Allah akan membalesnya.
Membalasnya. Piye mbalase? Mungkin kita akan diberi cobaan agar tidak melakukan hal-hal yang berdosa. Cobaannya berupa apa? Sakit. (Yan)

Lalu mengapa Tuhan menghukum orang yang berbuat jahat? Han ya diberi cobaan, itu bukan hukuman. Bukan hukuman, hanya cobaan. Hanya cobaan? Kalau dimasukkan dalam neraka, apa itu? Hukuman? itu hanya balasan yang sefimpal. Alas apa? Atas perbuatan d dunia. Ketika berbuaf baik, besok akan dibalas baik. (Yan)

d. Miskin orisinalitas gagasan, Orisinalitas gagasan adalah keaslian gagasan yang disesuaikan dengan tahap pemikiran anak. Miskinnya orisinalitas gagasan berkait dengan begitu banyak gagasan yang diadaptasi oleh responden anak merupakan gagasan yang diperoleh dari pengajaran yang dilakukan oleh guru mengenai Tuhan dan hubungan Tuhan dengan manusia. Gagasan responden lebih mirip gagasan orang dewasa yang ditangkap anak selama pengajaran mengenai Tuhan oleh orang dewasa (guru dan orangtua). Peneliti menangkap its dari proses membandingkan beberapa gagasan mengenai Tuhan yang diungkapkan responden anak dengan beberapa kasus yang peneliti peroleh dari dokumen pribadi maupun dari diskusi dengan rekan sejawat. Misal dengan gagasan Icha (5 tahur) yang sambil meniup terompet pada malam Tahun Baru 2004 berkata, "Bèn Gusfi Alloh brèbèg(BiarTuhanitubising).. tcha menurut pandangan pereliti telah mempertemukan dua gagasan yakni gagasan bahwa Tuhan itu dapat mendengar dan gagasan yang berasal dari pengalaman bahwa ketika ditiup terompet keras-keras akan membuat bislng, mengganggu pendengaran. Kedua gagasan ini 
dipertemukan sehingga terciptalah gagasan, "Bèn Gusti Alloh brèbeg (Biar Tuhan itu bising). Gagasan orisinal biasanya merupakan jawaban yang bersifat spontan yang bukan dihasilkan dari kumpulan gagasangagasan yang diperolehnya melalui orang lain. Plaget (Ginsburg, 1997) menyatakan pemikiran anak yang spontan itu menggambarkan bagaimana anak melihat dunia, bagaimana anak sebenamya berpikir, dan bagaimana memecahkan masalahnya yang secara kualitiatif berbeda dengan cara dan pandangan orang dewasa mengenai dunia. Pemikiran spontan anak mengenai Tuhan merupakan gagasan dan kepercayaan anak yang dibangun dalam percobaannya untuk menginterprestasikan istilah-Istilah dan praktik keagamaan yang melampaui batas pengertiannya (Elkind, 1964).

e. Tuhan merupakan sosok yang senantiasa dipenuhi dengan kebaikan, kesucian dan kemuliaan. Tuhan tampak sebagai sosok yang baik dan tidak mungkin jahat. Tuhan dianggap baik karena Tuhan telah memberikan begitu banyak anugerah di dalam kehidupan ini.

Tidak. Tapi kalau sama penjahat, orang yang berbuat jahat, orang yang berbohong. pencuri, Tuhan jahat tidak? (responden terdiam lama) Tidak. Lalu mengapa Tuhan menghukum orang yang berbuat jahat? Hanya diberi cobaan, itu bukan hukuman. Bukan hukuman, hanya cobaan. Hanya cobaan? Kalau dimasukkan dalam neraka, apa itu? Hukuman? itu hanya balasan yang setimpal. Atas apa? Atas perbustan df dunia. Ketika berbuat baik, besok akan dibalas baik. (Yan)

f. Sosok Tuhan tidak dapat diajak berbicara secara langsung dikarenakan wujud-Nya yang tidak tampak, namun dengan perantara doa Tuhan akan dapat diajak untuk berkomunikasí.

g. Gagasan anak mengenai Tuhan sudah mulai berkembang ke arah gagasan Tuhan suprapersonal yakni gagasan Tuhan yang jauh melampaui sifat-sifat manusia.

Tapi Tuhan sendiri jahat atau tidak? Tidak. Tapi kalau sama penjahat, orang yang berbuat jahat, orang yang berbohong, pencuri, Tuhan jahat tidak? (responden terdiam lama) Tidak. Lalu mengapa Tuhan menghukum orang yang berbuat jahat? Han ya diberi cobaan, itu bukan hukuman. Bukan hukuman, hanya cabaan. Hanya cobaan? Kalau dimasukkan dalam neraka, apa itu? Hukuman? ltu hanya balasan yang setimpal. Atas apa? Atas perbuatan of dunia. Ketika berbuat baik, besok akan dibatas baik. (Yan)

h. Berkembangnya rasa bersalah sebagai penanda telah berkembangnya hati nurani anak yang akan membantu anak melakukan perilaku-perilaku baik dan menghindari perilaku-perilaku tidak baik. Ini didasarkan pada pernyataan responden anak pada cupilkan wawancara sebagai berikut:

Kalau kita orang Isiam yang enggak sengaja, walaupun nggak sengoja itu, kalau aku tho itu rasanya merasa bersalah banget. Nggak enak gitulah. Nggak enak itu? Eneg gimana lah. Di dada? Pokoknya sebel juga kenapa nggak ngati-ati, (ka)

3. Faktor-faktor yang mempengaruhi pernbentukan konsep Tuhan pada anak adalah sebagai berikut:

a. Pengajaran mengenai Tuhan dan hubungan Tuhan dengan manusia. Ini merupakan faktor dominan yang mempengaruhi terbentuknya konsep Tuhan pada anak. Tidak dapat 
dipungkiri bahwa pada masa akhir anak-anak telah mampu mengadaptasi gagasan-gagasan orang dewasa di mana itu menggambarkan kepercayaankepercayaan secara teologis mengenai Tuhan. Pengajaran mengenai Tuhan dan hubungan Tuhan dengan manusia sendiri dipengaruhi beberapa faktor yaitu:

1) Faktor kognitif yang berupa pengetahuan orang dewasa (orangtua dan guru) mengenal doktrin agama dan pengetahuan lain selain pengetahuan agama.

2) Faktor sosial adalah seberapa besar cakupan sosial seseorang. Keluarga tempat dilahirkan dan dibesarkan, lingkungan pendidikan yang diterima individu, teman sebaya, tradisi yang melingkunginya, ataupun tekanan-tekanan lingkungan sosial di mana Individu harus menyesuaikan diri dengan berbagai pendapat dan sikap yang disetujui lingkungan. Semua itu akan mempengaruhi terbentuknya suatu keyakinan dan perilaku keagamaan seseorang. ini dapat dilihat pada apa yang dikemukakan oleh ibu responden anak dua sebagai berikut:

Makanya Bapak saya dulu mulai itu, ya ngajarkan itu, ya agama itu...anu sholat adalah tiang agama. Kalau sholatnya salah kan nanti kalau kamu nggak sholat, nggak ini berbuat apa saje itu belum tentu diterima, kalau misalnya nggak sholat. Gitu, kalau dulu Bapak saya ngajarinya gitu. (buYan)

3) Faktor personal yang terdiri dari:

(a) Kendaia diri. Kendala ini biasanya dirasakan karena orangtua merasa pengetahuan agama yang dimilikinya masih kurang untuk melakukan pengajaran mengenai Tuhan.

... tapi kalau masalah hal yang sifatnya religius saya memang tens terang saye menyadari bahwa ee...kapasitas saya tentang, tentang religius, khususnya tentang religius ya, konteksnya konteks religius dalam artian tentang e...misalnya apa ee, hapalan doa, kemudian tejemahannya gimana, esensinya gimana artinya kalau anunya gimana u, saya terus terang tidak... (Ayah Yan)

(b) Keyakinan yang bersifat individuai. Keyakinan ini berasal dari proses verifikasi kebenaran gagasan keTuhanan yang pernah diperoleh melalui doktrin keagamaan.

... "Wah, Allah betul-betul Maha Penyayang, begitu Iho." Katakanlah begini, Mas misalnya katakanlah dua setengah persen, saya keluarkan sekian, saya dengan penuh, saya coba untuk berlatih menyisihkan untuk mereka yang kekurangan misalnya pada saudara, teman-teman, its ya, kok ya, akhimya ada-ada saja, yang kadang its of luar, df luar perhilungan kita. Kita ikhlas duluan karena Allah juga kadang-kadang ya, memang rezeki itu memang dari manamana dan tidak disangkasangka. thu akibat-akibat kalau menurut saya, its yang saya rasakan. Ya, saya selalu merasakan itu. Entah itu ilmu gathuk-gathuke, tapi saya yakin, Pak. Saya yakin. (Ayah ika) 
Pengajaran mengenai Tuhan dan hubungan Tuhan dengan manusia berlangsung dengan dua jalan yakni (1) pengajaran langsung yakni pengajaran mengenai doktrin agama dan (2) pengajaran tidak langsung, pengajaran yang tidak langsung ditujukan untuk mengajarkan anak mengenai Tuhan namun memiliki pengaruh pada anak untuk memahami gagasan-gagasan pada doktrin agama (kebiasaan berupa kebiasaan-kebiasaan perilaku orangtua yang menghubungkan perilaku tertentu dengan perintah dan larangan Tuhan, sikap, dan perilaku orang dewasa terhadap ritual-ritual keagamaan).

b. Persepsi, pengalaman, konsep, dan pengetahuan terhadap sesuatu lain. Konsep Tuhan sebagai konsep yang tinggi tingkat keabstrakannya di dalam proses pembentukan akan "menggunakan jasa" persepsi, pengalaman, konsep, dan pengetahuan anak mengenai hal yang lain. Anak selanjutnya menggolah persepsi dan pengetahuan yang pernah didapatkan untuk membantu mengartikan dan memberi penanda makna pada kata Tuhan, sifat, dan

- aktivitas Tuhan. Pemahaman anak mengenai Tuhan begitu banyak akan terbantu dengan melihat realitas benda yang leblh konkret, melihat hubungan antarmanusia yang kemudian dipersepsikannya. Berikut ini cuplikan wawancara yang akan menggambarkan bagaimana responden anak menggunakan pengetahuan dan pengalamannya mengenai benda-benda di sekitarnya untuk membantu menerjemahkan mengenai perbuatan Tuhan.

Apakah Tuhan bisa bikin gelas? Tidak. Kenapa? Tuhan hanya menciptakan... Karena gelas ini terbuat dari kaca dan kaca terbuat dari... (terdiam lama) Dari apa? $H m m$...Dari batu? Oh, ya darl batu dan Tuhan hanya menciptakan batu itu dari. dari endapan bumi, endapan lahar. (Yan)

c. Pengaruh yang berasal media informasi, buku, dan teman sebaya.

Sebagaimana orang dewasa keberadaan faktor lingkungan sosial dan media informasi akan memberi pengaruh yang cukup berarti di dalam pembentukan konsep Tuhan pada anak. Responden anak dua misalnya mengadaptasi metafora "kembali ke tangan Tuhan" yang dldaptkannya dari sinetron yang dilihatnya di televisi untuk menyiratkan makna "kematian",

Merenung tentang apa? Tentang Tuhan?Pernah. Apa yang kamu renungkan saat itu? Kapan aku dapat kembali ke tangan Tuhan...Kapan kamu bisa kemball ke tangan Tuhan, maksude? Atau mati, atau meninggal. (Yan)

Kembali ke tangan Tuhan itu kalimat..., itu kamu dapatkan dari mana? Dari... (terdiam lama) $T V$, dari suara-suara masyarakat.Dari TV. Acara opo? Kembali ke tangan Tuhan? Acara apa?Atau dari guru, atau dari masyarakat, atau dari temen, Iupa saya. Lupa? Tapi kamu pernah mendengarnya? Pernah. Paling banyak of TV. Dari apa? $D$ sinetron-sinetron. (Yan)

d. Pergeseran gagasan. Gagasan yang dikemukakan terkadang mengalami sediklt pengalihan makna darl gagasan semula yang diajarkan (dikenalkan secara teologis).

E... kalau semua ifu disayang, tapi tidak semua diasihi. Yang diasihi itu yang taat-taat saja dan yang bertaqwa. Yang mendapatkan kasih sayang, gok-gék, yang mendapat yang mendapat penyayang dan pengasih itu, itu tuh, nanti apa namanya hanya orang-orang yang 
bertaqwa. Yang baik-baik saja. Tapi Allah menyayangi semua makhluk. Semuanya disayang. Tapi tidak semuanya mendapat apa... asih-asih itulah. Ape to yang panggilannya? Jadi orang yang dikasih dan disayang itu? Hanya orang-orang yang bertaqwa. (Ika)

Pergeseran makna ini terjadi karena tampaknya responden masih bingung untuk membedakan gagasan Pengasih dan Penyayang. Keduanya hampir mirip, cuma memang ada bedanya. Dalam kepercayaan Islam, sifat Pengasihnya Allah itu beriaku untuk semua makhluk, sementara Penyayang-Nya Allah litu hanya untuk hamba-hamba-Nya yang bertaqwa. Responden memahami Pengasih sebagai sesuatu yang khusus yang diberikan kepada orang-orang yang taat. Ini terjadi karena responden memahami kata Pengasih adaiah kata bentukan dari kata sifat "asih" yang berarti kasih (kata sifat). Padahal kata Pengasih dalam hal ini berasal bentukan dari kata "kasih" (kata kerja) yang berarti "member". Sehingga kemudian mengartikan orang yang diasih itu lebih tinggi tingkatannya dibandingkan orang yang disayang. Namun walaupun konsepnya mengalami pergeseran, secara esesial responden masih dapat menangkap makna yang terungkap dari gagasan tersebut.

e. Doa dan efek dari doa. Doa di satu sisi adalah sebentuk permintaan dalam kegiatan keagamaan. Namun doa juga selalu dihubungkan dengan perasaan tenang yang diperoleh sesudahnya. Keglatan doa akan terus diulang karena dapat menggantikan ketegangan, kekhawatiran, dan kecemasan yang diakibatkan dari persoalan yang dihadapi seseorang.

Tenang. Tens merasa dilindungi? Ya Kalau mbaca Qur'an merasa tenang. Kalau nggak mbaca Qur'an? Ya blasa saja. Cumanlebih tenang. (lka) f. Proses individual. Proses individual yang peneliti temui pada responden anak yang membantunya untuk memperkuat gagasan mengenai Tuhan dan hubungan Tuhan dengan manusia adalah kegiatan bertanya dan kegiatan ber-refleksi. Bertanya dan kegiatan refleksi dalam tingkatan yang sederhana adalah dua aktivitas yang peneliti temui ada pada diri responden anak yang membantunya untuk mengembangkan lebih jauh mengenai konsep Tuhan. Bertanya merupakan sebuah cara yang dilakukan anak untuk mengetahui lebih jauh mengenai objek yang menggugah rasa ingin tahunya. Beberapa pertanyaan-pertanyaan yang dikemukakan oleh responden anak adalah sebagal berikut, "Allah itu punya teman nggak?" " Allah itu of mana? Lho Tuhan of mana-mana. Katanya satu kok di mana-mana. Tuhan Maha Tahu tya tapi dimana?" (1ka): "Tuhan menciptakan hewan pertama kali tahun berapa?, "Tuhan its ada berapa?", "Tuhan itu punya anak nggak"?, "Allah itu dimana?", "Allah ifu wujudnya apa?" "Allah itu bagaimana bentuknya?"(Yan).

Selain bertanya, peneliti juga menemukan keglatan refleksi sebagai suatu cara untuk anak memahami konsep Tuhan. Kegiatan refleksi ini peneliti temukan pada responden anak dalam bentuk perasaan sedih yang dialami responden dengan kesalahan-kesalahan yang dilakukannya terhadap orangtua maupun temantemannya. Sedih dengan sifat-sifat buruk yang dimiliki dan bertanya apakah dirinya dapat berubah ataukah tidak

Kan aku itu kalau punya salah sama temen-temen, apa sama Bapak-lbu, disengaja atau tidak disengaja. Disengaja atau tidak disengaja? Kalau kamu seperti itu rasanya? Sedih, kenapa aku seperti ifu. Apakah aku bisa berubah?(ka)

4. Dinamika Psikologis Pembentukan KonsepTuhan padaAnak 
Dinamika psikologis terbentuknya konsep Tuhan pada anak adalah proses interaksi keenam faktor yang mempengaruhi terbentuknya konsep tersebut melalui sebagai berikut:

a. Proses transformasi gagasan yakni proses pengalihan gagasan mengenai Tuhan dan bagaimana Tuhan berhubungan dengan manusia.

b. Proses "membantu untuk mengartikan" yakni proses di mana persepsi, pengalaman, konsep dan pengetahuan lain yang tidak ada hubungannya secara langsung dengan konsep Tuhan yang membantu untuk mengartikan Tuhan, sifat-sifatTuhan, dan aktivitasTuhan.

c. Proses untuk menguatkan dan mengembangkan gagasan tentang Tuhan yang diperoleh anak melalui pengajaran, baik itu pengajaran langsung dan pengajaran tidak langsung.

Pembentukan konsep Tuhan pada anak sangat bergantung pada proses transformasi gagasan (pengalihan gagasan) yang litu dapat berasal dari pengajaran mengenai Tuhan dan hubungan Tuhan dengan manusia ataupun pengaruh dari teman sebaya, bacaan, maupun medla informasi lain. Namun gagasan-gagasan Tuhan yang anak peroleh melalul proses tranformasi gagasan untuk tersusun menjadi konsep membutuhkan persepsi, pengalaman, konsep, dan pengetahuan lain yang akan membantu mengartikan gagasangagasan yang diperoleh melalui orangtua, guru, maupun doktrin agama. Kedua proses ini akan semakin berkembang dan dikuatkan karena đi dalam diri anak terdapat proses individual yakni bertanya dan kegiatan ber-refleksi dan ada pengaruh dari doa dan kegiatan praktik-praktik keagamaan. Akibat yang dihasilkan dari doa memiliki potensi untuk membuat anak mengerti mengenai pengalaman rasa ketika bersentuhan dengan realitas ketuhanan.

\section{Diskusi}

Konsep Tuhan pada anak usia akhir operasional konkret (10-11 tahun) cenderung dihasilkan dari proses tranformasi gagasan mengenai Tuhan yang dilakukan oleh orangtua maupun guru melaiui pengajaran. Di dalam proses pengajaran, baik yang dilakukan secara langsung maupun tidak langsung, akan sangat dipengaruhi oleh konsep orang dewasa mengenai Tuhan. Konsep orang dewasa sendiri dihasilkan dari interaksi tiga faktor yakni (1) faktor kognitif, yakni pengetahuan yang dimillki orang dewasa mengenal doktrin (sistem kepercayaan dalam suatu agama) dan pengetahuan-pengetahuan lain yang didapatkannya dari ilmu dan kebudayaan serta dari pengalaman hidup sehari-hari; (2) faktor sosial, adalah seberapa besar cakupan sosial seseorang. Keluarga tempat seseorang dibesarkan, lingkungan pendidikan yang diterima, teman sebaya, tradisi yang melingkungi, ataupun tekanantekanan lingkungan sosial of mana individu harus menyesuaikan dirli (3) fahtor personal yakni kendala diri dan keyakinan yang bersifat individual. Kendala diri yang biasanya terjadi pada proses tranformasi gagasan adalah masalah sedikitnya pengetahuan yang dimiliki mengenai Tuhan dan hubungan Tuhan dengan manusia. Sementara itu keyakinan yang bersifat individual dihasilkan dari doktrin yang terverifikasi gagasannya pada waktu berhadapan dengan pengalaman hidup sehari-hari. Pembuktian pada pengalaman sehari-hari Ini bukan hanya akan memberikan bukti-bukti argumentatif semata, namun akan memberikan "pengalaman rasa" pada suatu gagasan mengenai Tuhan yang didapatkan individu melalui doktrin keagamaan. Kebanyakan orang menerima kepercayaan secara pasif dari apa yang diterimanya dari pengajaran kepercayaan oleh orangtua atau masyarakat di mana ia tinggal atau dibesarkan. Pengalaman-pengalaman hidup cenderung akan menantang gagasan-gagasan 
ketuhanan untuk dibuktikan fungsinya bagi seseorang. Sistem kepercayaan pada suatu agama akan memberikan pengetahuan objektif mengenai Tuhan melalui kitab suci dan pemberitaan nabi (utusan Tuhan), sementara pengalaman-pengalaman hidup akan memberikan pengetahuan subjektif mengenai Tuhan yang dihasilkan dari penghayatan gagasan ketuhanan dalam kehidupan (Izutsu, 1997; Jacobs, 2002).

Maulana Jalaluddin Rumi pernah mengungkapkan ini dengan berkisah mengenai pertemuan antara Musa as dengan seorang penggembala yang berbicara akrab dengan Tuhan; ingin membantu Tuhan, menjahit sepatu-Nya, menyisir rambut, mencuci pakaian, membunuh kutu-kutu-Nya, menyediakan susu untuk Tuhan dan mencium tangan dan kakl-Nya menjelang tidur. Musa sangat terkejut dan sangat marah. Siapa gerangan teman bicara yang dibayangkan si penggembala ini? Musa beranggapan kalau penggembala itu berblcara seperti itu dengan Pencipta langit dan burni seperti berbicara dengan pamannya. Penggembala itu bertobat dan mengembara membawa kegelisahannya ke padang pasir, namun Tuhan menegur Musa. Tuhan tidak menghendaki kata-kata ortodoks (kolot, kaku), tetapi cinta yang membakar dan kerendahan hati (Armstrong, 2002).

Kisah Ini memberikan pemahaman bahwa bagaimanapun dalam kepercayaan individu terhadap Tuhan melalui agama yang dianutnya akan membawa pemahaman yang berbeda, dikarenakan tingkat pengetahuan dan penghayatan yang berbeda. Akhimya setiap individu yang meyakini keberadaan Tuhan, mau tidak mau tetap akan memilih bahasa yang individual. Inilah yang seringkali akan membantu individu mencapai kedekatan rasa dengan Tuhannya.

Pentingnya pengalaman keberagamaan pada orangtua tampaknya akan ada di sint. Penghayatan of mana gagasan bukan lagi hanya kata dan pengetahuan mengenai Tuhan. Tuhan sudah diresapi dan dirasakan dalam kehidupan, sehingga ketika proses pengajaran berlangsung tidak hanya pengetahuan tentang Tuhan yang tersampaikan tetapi juga perasaan kerinduan keberakaran akan Tuhan juga akan turut dirasakan oleh anak. Selain itu, gagasan Tuhan yang terlambari pengatahuan rasa membuat Tuhan lebih hidup, menarik, dan menantang anak untuk lebih jauh mendalaminya sebagai sebuah Realitas.

Sementara itu selain proses transformasi gagasan, pembentukan konsep Tuhan pada anak akan banyak terbantu oleh persepsi, pengalaman, pengetahuan, dan konsep lain yang anak miliki yang tidak secara langsung berhubungan dengan konsep Tuhan. Konsep Tuhan sebagai konsep yang tinggi tingkat keabstrakannya di dalam proses pembentukan akan "menggunakan jasa" persepsi, pengalaman, konsep, dan pengetahuan anak mengenai hal yang lain. Anak pertarna kali melihat dunia dengan begitu banyak hal yang berbeda. Anak kemudian mempersepsikan dan menyusunnya menjadi konsep-konsep yang berasal dari pengalaman ini, yang awalnya disimbolkan dalam bentuk gambar mental dan menggunakan kata dan pengungkapan verbal sesudah belajar bahasa (Goldman, 1964).

Anak selanjutnya mengolah persepsi dan pengetahuan yang pemah didapatkan untuk membantu mengartikan dan memberi penanda makna pada kata Tuhan, sifat, dan aktlvitas Tuhan. Pemahaman anak mengenai Tuhan begitu banyak akan terbantu dengan melihat realitas benda yang lebih konkret, melihat hubungan antara manusia yang kemudian dipersepsikannya. Anak dengan indera dan pikimya lebih mengenal secara konkret piring. kacang. gelas dibandingkan dengan Realitas Tuhan yang abstrak. Konsep anak mengenai piring, kacang, gelas, air sirup akan mengarahkan anak pada proses pembandingan dengan ciptaan Tuhan lainnya: alam semesta, binatang, tumbuhan dan lain-lainnya. Pengalaman berhubungan dengan orang lain dan orangtua, mendapatkan perhatian, 
kasih sayang, hukuman, dimarahi orangtua akan membantu anak untuk membantu mengartikan bagaimana sifat-sifat dari Tuhan. Walaupun proses kognitif ini jelas bukan proses sederhana, karena misalnya untuk mendapatkan konsep "Pengasih" dan "Penyayang"-nya Tuhan anak tidak hanya didasarkan pada pengalaman diperhatikan, dikasihl, disayangi oleh orangtuanya. Sernakin luas interaksi anak dengan dunia luar, maka semakin berkembang konsep kasih sayang, sehingga semakin luas pula pemaknaan anak terhadap sifat "Pengasih" dan "Penyayang"-nya Tuhan.

Proses kedua ini jelas sekali menyiratkan bahwa pemahaman anak mengenai Tuhan seiain membutuhkan tahapan dan pengetahuan dasar mengenai banyak hal, juga menyiratkan sebuah keharusan bagi orangtua dan guru untuk menampakkan keindahan sifat-sifal Tuhan d dalam dirinya sebelum melakukan pengajaran. Kebaikankebaikan Tuhan yang diejawantahkan dalam kehidupan sehari-hari dengan perkataan, perbuatan, dan tindakan. Hai ini jelas sekali akan membantu anak untuk menggabungkan kesan kasih sayang yang didapatkan oleh orangtuanya dengan gagasan Tuhan yang Pengasth dan Penyayang.

Proses yang ketiga adaiah proses untuk menguatkan dan mengembangkan gagasan mengenai konsep Tuhan pada anak. Peneitian ini menemukan bahwa proses individual seperti bertanya dan ber-refleksi akan banyak membantu anak untuk mengembangkan gagasannya mengenai Tuhan. Bertanya merupakan sebuah cara yang dilakukan anak untuk mengetahui lebih jauh mengenai objek yang menggugah rasa ingin tahunya (Hurlock, 2000). Pada usia sesudah tiga tahun, seorang anak mulai banyak mengajukan pertanyaan dengan "mengapa". Anak mempertanyakan dirinya dan lingkungan. Pada masa itu, anak ingin mengerti sebab finalis (sebab yang terakhir) suatu persoalan. Anak menginginkan suatu jawaban akhir. Oleh karena itu, anak akan bertanya terus kalau beium terjawab (Suparno, 2001).

Proses individual yang lain adalah berrefleksi. Refleksi tidak lain merupakan pertimbangan internai yang berarti saku diskusi yang diadakan dengan dirinya sendiri persis seperti diskusi itu dapat diadakan dengan teman atau lawan bicara yang nyata. Refleksi dapat dikatakan sebagai diskusi sosial yang diinternalisasi Refieksi didapatkan anak pada proses tranformasitransformasi sosiai ketika anak muiai dapat memandang sudut pandangnya dan sudut pandang orang iain. Anak tidak mencampuradukkan antara sudut pandang dirinya dengan sudut pandang orang iain (Piaget, 1989).

Selain itu doa dan efek doa akan membantu anak untuk mengembangkan dan menguatkan gagasan Tuhan of dalam dirinya. Doa adaiah sebentuk permintaan dalam kegiatan keagamaan, namun doa juga seialu dihubungkan dengan perasaan tenang yang diperoieh sesudahnya karena berkurang atau hilangnya ketegangan (tension) yang timbui dari keyakinan bahwa persoaian yang dihadapi teiah diungkapkan kepada Tuhan melalui doa (Thouiess, 2000). Kegiatan doa akan terus diulang karena dapat menggantikan ketegangan, kekhawatiran. dan kecemasan yang diakibatkan dari persoaian yang dihadapi seseorang. Perasaan menurut Paloutzian (1996) terkadang digunakan sebagai indikasi bagi individu ada atau tidaknya kehadiran Tuhan d dalam diri mereka. Seseorang yang merasakan ketakutan atau cemas sering disimpulkan bahwa diri mereka sedang jauh dari Tuhan, karena berdosa atau Karena Tuhan sedang meninggakan orang tersebut. Efek doa yang dapat dirasakan anak merupakan daya penguat yang hebat untuk mengukuhkan kehadiran Tuhan, karena Tuhan bukan lagi kata tapi rasa. Tuhan yang abstrak itu dapat dirasakan kehadiranNya, walaupun tidak dapat dilihat kehadiran-Nya. 

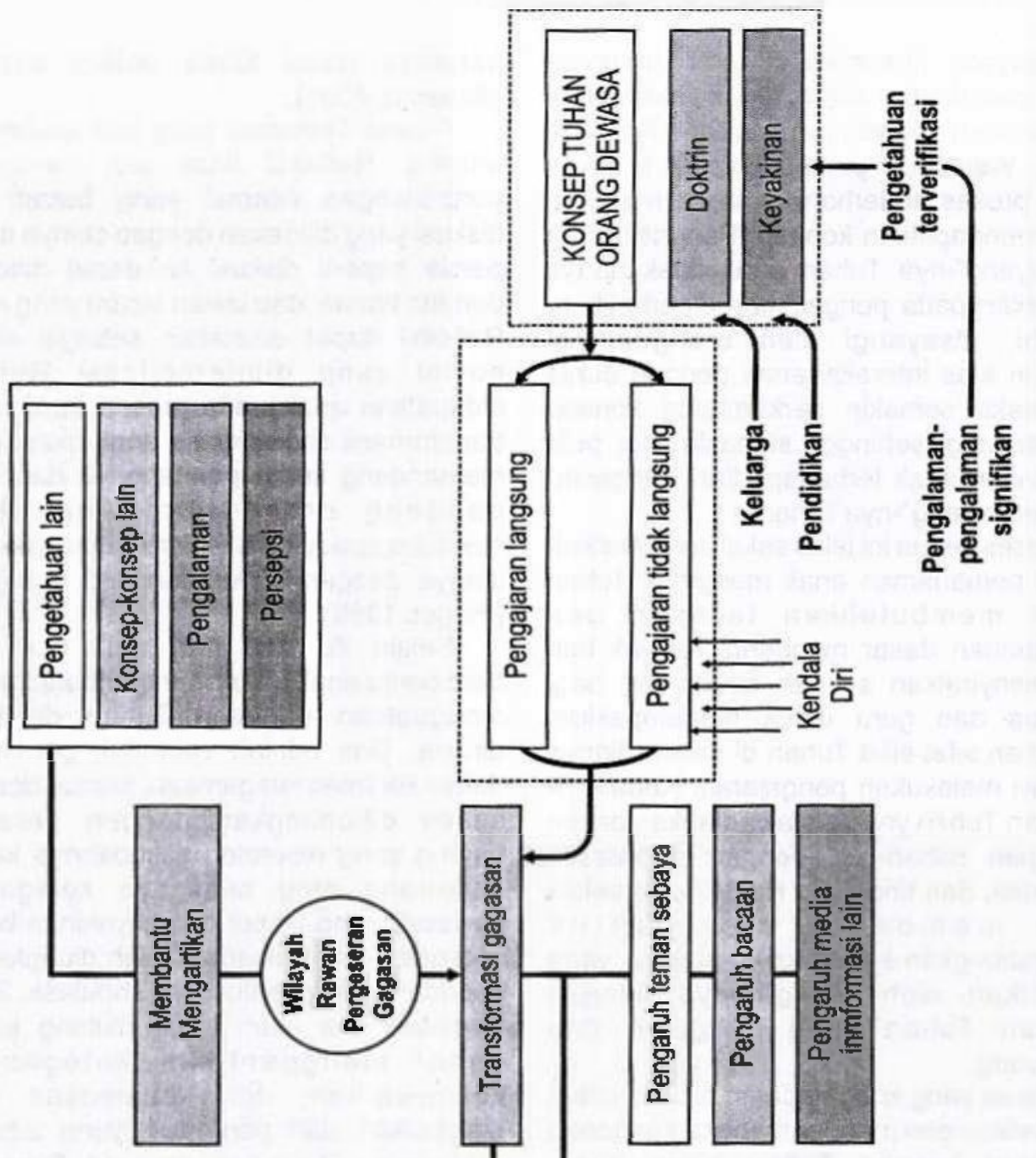

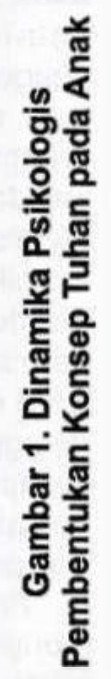

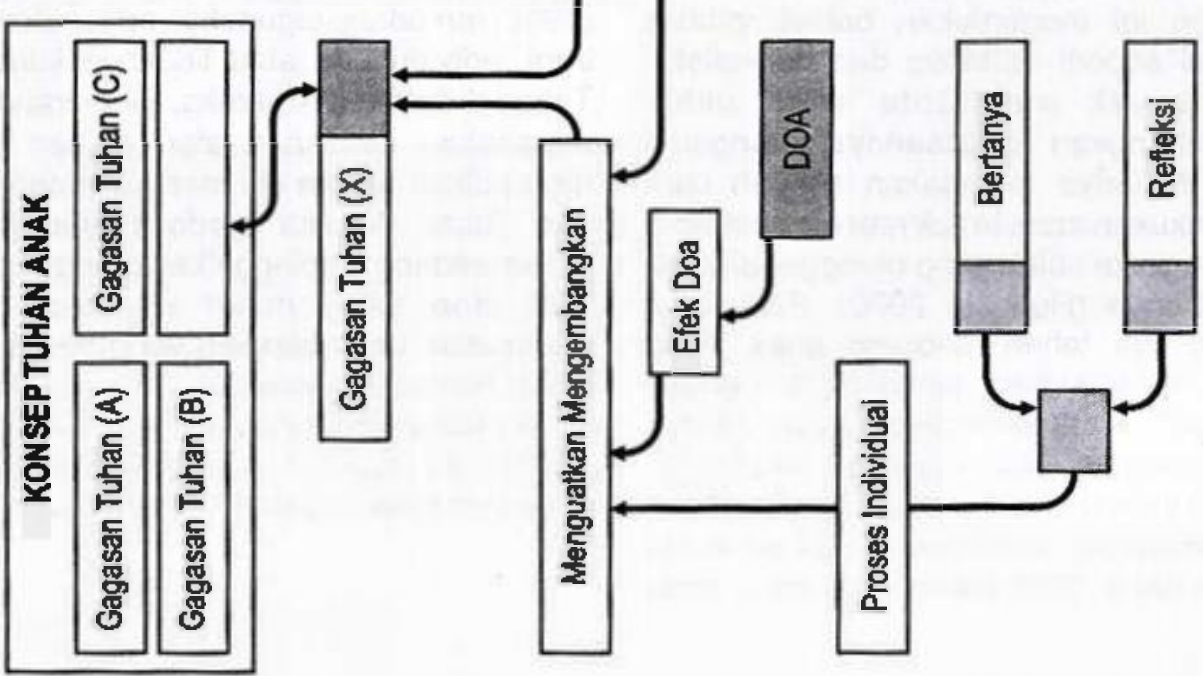




\section{Penutup}

Berpijak dari hasil penelitian maka dapat disarankan bagi orangtua dan guru untuk melakukan pengajaran Tuhan dalam situasi yang dialogis dan reflektif dalam kenyataan hidup Sehari-hari akan membantu anak untuk lebih merasakan Tuhan sebagai realitas dan sebagai nilai yang individual dimiliki. Tuhan akan lebih baik diajarkan sebagai sosok yang dekat, penuh kasih sayang, melindungi dan dapat diminta pertolongan dan tidak diajarkan dengan situasi yang mengancam penuh dengan ketegangan. Orangtua dan guru diharapkan juga memberi kesempatan bagi anak untuk bertanya dan mendapatkan jawaban sendiri atas gagasan-gagasan Tuhan yang ada di dalam doktrin agama melalui pengalaman-pengalaman hidup yang dihadapi dengan tetap dalam bimbingan orangtua dan guru. Hukuman Tuhan diajarkan sebagai konsekuensi terhadap kesalahan yang diperbuat dan disampaikan dalam situasi yang penuh dengan kelembutan dan kasih sayang.

\section{Daftar Pustaka}

Armstrong, K 2002. Sejarah Tuhan Kisah Pencarian Tuhan yang Dilakukan Oleh Orang-orang Yahudi, Kristen, dan Islam Selama 4000 Tahun. Bandung: Penerbit Mizan Utama.

Coles, R. 1990. The Spiritual Life of Children. Boston: A Painter Davidson Book Houghton Mifflin Company.

Daradjat, Z 1993. IImu Jiwa Agama, Jakarta: Penerbit Bulan Bintang.

Darmaningtyas. 1999. Pondidikan Pada dan Setelah Krisis. Yogyakarta: Pustaka Pelajar.

Goldman, P.J. 1964. "Researches in Religious Thinking dalam L.B. Brown (eds). Psychology and Religion. Australia: Penguin Education.
Hidajati, A. 202. Anakku dan Tuhan.Catatan Perjalanan Mengajar Anak-anak. Yogyakarta: Putra Langit.

Hurlock, E.B. 1996. Psikologi Perkembangan Suatu Pendekatan Sepanjang Rentang Kehidupan Edisi Lima. Jakarta: Erlangga. 2000. Perkembangan Anak Jilid II. Jakarta: Erlangga.

Izutsu, T.1997. Relasi Tuhan dan Manusia. Pendekatan Semantik temadap Al Qur'an. Yogyakarta: Tiara Wacana.

Jacobs, T. 2003. Paham Allah dalam Filsafat, Agama-agama dan Teologi. Yogyakarta: PenerbitKanisius.

Mulkhan, A.M. 2002. Nalar Spiritual Pendidikan Solusi Problem Fllosofis Pendidikan Islam. Yogyakarta: Tiara Wacana.

Mönks, F.J, Knoers, A.M.P. dan Haditono,S.R. 1999. Psikologl Perkembangan Pengantar dalam Berbagal. Bagiannya. Yogyakarta: Gadjah Mada University Press.

Paloutzian, R.F. 1996. Imitation to the Psychology of Religion. 2nd Edition. Boston: Allyn and Bacon.

Piaget, J. 1988. Antara Tindakan dan Pikiran. Jakarta: PT Gramedia Pustaka Utama.

Stoppard, M. 1997. Questions Children Ask \& How to Answer Them. London: Dorling KIndersley.

Supamo, P. 2001. Teori Perkembangan Kognitif Joan Plaget. Yogyakarta: Kanisius.

Thouless, R.H. 2000. Pengantar Psikologl Agama. Jakarta : PT Raja Grafindo Persada.

Tubbs, S.L dan Sylvia Moss.1996. Human Communication : Konteks-Konteks Komunlkasi. Bandung : Remaja Rosdakarya. 